\title{
TINJAUANTERHADAP BILANGAN 666 DALAM WAHYU 13
}

\author{
Roby Setiawan \\ Sekolah Tinggi Theologia Baptis Indonesia \\ Jl. Simongan, No. 1, Barusari, Semarang Barat, 50141 \\ Email: drrobys@gmail.com
}

\begin{abstract}
Roby Setiawan, Review of Numbers 666 In Revelation 13. The number 666 mentioned in Revelation 13 has been crowded into talks, but some interpretations of such numbers by some Christians are linked to certain trademark logos so that there is a tendency to impose the business of others by using these interpretations. The writer afraid that if the number 666 is interpreted literally, then Christianity would become superstitious religion, as some people are not happy with the number 4 or 13 because it is considered an unlucky number, in contrast they are very happy with the numbers 8 and 9 , because it is considered to bring fortune which is durable. Therefore it is necessary to understand what is the number 666. To understand the meaning of the number 666, the writer makes a historical-theological review so as to obtain a background image related to the number 666 in Revelation 13. The results show that the number 666 is associated with gematria method, but for the writer, the interpretation of the number 666 using gematria method is not acceptable and still need to be tested more deeply so as not to lead to inaccurate allegations. While related to its context, the number 666 is closely related to the symbol as the Book of Revelation is full of symbols. The result of the contextual analysis of Revelation 13 then number 666 represents the human effort that seeks to equal God to achieve unlimited power, yet they fail.
\end{abstract}

Key Words: gematria, revelation, 666, antichrist.

ABSTRAK: Roby Setiawan, Tinjauan Terhadap Bilangan 666 Dalam Wahyu 13. Bilangan 666 yang disebutkan dalam Wahyu 13 telah ramai menjadi pembicaraan, tetapi beberapa penafsiran terhadap bilangan tersebut oleh sebagain orang Kristen dikait-kaitkan dengan logo merek dagang tertentu sehingga ada kecenderungan menjatuhkan bisnis orang lain dengan menggunakan tafsiran tersebut. Penulis kuatir jika bilangan 666 ini ditafsirkan secara hurufiah, maka kekristenan akan menjadi agama tahyul, seperti yang dipercayai oleh sebagian orang yang tidak senang dengan angka 4 atau 13 karena dianggap angka sial, sebaliknya mereka sangat senang dengan angka 8 dan 9, karena dianggap membawa rejeki yang tahan lama. Oleh sebab itu perlu dipahami apa bilangan 666 tersebut. Untuk memahami makna bilangan 666, maka penulis melakukan tinjauan historis-teologis sehingga diperoleh gambaran latar belakang yang terkait dengan bilangan 666 dalam Wahyu 13. Hasil studi menunjukkan bahwa bilangan 666 dikaitkan dengan cara gematria, tetapi bagi penulis, penafsiran terhadap bilangan 666 dengan menggunakan gematria tidak dapat diterima dan masih perlu diuji dengan lebih dalam sehingga tidak menimbulkan dugaan-dugaan yang tidak tepat.Sementara berkaitan dengan konteksnya, bilangan 666 sangat berkaitan dengan simbol sebagai Kitab Wahyu penuh dengan simbol. Hasil dari analisis konteks Wahyu 13 maka bilangan 666 melambangkan usaha manusia yang berusaha menyamai Allah untuk mencapai kuasa yang tidak terbatas, namun mereka gagal.

Kata Kunci: gematria, wahyu, 666, antikris.

\section{PENDAHULUAN}

Bilangan '666' ini walaupun hanya disebut sekali dalam Alkitab (Why. 13:18), tetapi ramai dibicarakan dan ditafsirkan secara beragam oleh sebagian orang karena menjadi lambang dari antikris. Mary Stewart Relfe pernah mengait-ngaitkan bilangan 666 dengan barcodes yang terdapat di produkproduk barang. Ia juga menafsirkan, bahwa '666' akan muncul dari Masyarakat Ekonomi Eropa
(MEE). Pada waktu Mary Stewart Relfe menulis bukunya (th. 1982), MEE masih beranggotakan 10 negara (bnd. '10 tanduk' di Daniel 7:20; Wahyu 13:1). Dia berkata, bahwa Brussels di Belgia, sebagai ibukota MEE, didirikan dalam bentuk salib. Menurutnya, dari situlah seorang Kaisar dari Kerajaan Roma akan bangkit lagi, 'pemimpin ekonomi yang tidak bisa dibantah lagi' (Relfe, 1982, p. 249-252). Namun, tafsiran ini gugur dengan sendirinya setelah 
anggota MEE bertambah jumlahnya, bukan lagi 10 . Sekarang, MEE sudah tidak ada lagi, dan menjadi EU (Economic Union) yang beranggotakan lebih dari 10 negara.

Sebagian orang Kristen lainnya berani mengait-ngaitkan bilangan 666 ini dengan logo merk dagang tertentu yang produknya tersebar di berbagai negara. Beberapa tahun yang lalu, sebagian orang malah menyebarkan isu tersebut dengan menuliskan surat kepada banyak orang Kristen untuk, masingmasing, melipatgandakan selembar surat itu kepada minimal 20 orang temannya, dengan disertai 'ancaman": "Jika setelah menerima surat edaran ini, Anda tidak memperbanyak 20 kali dan mengirimkannya kepada teman-teman, maka akan terjadi musibah di dalam kehidupan Anda." Oleh sebab itu perlu berhati-hati agar isu agama tidak diperalat untuk menjatuhkan bisnis orang lain sehingga berdampak luas bagi kelangsungan hidup banyak orang yang menjadi karyawannya. Barclay (2007, p. 151) menjelaskan bahwa karena 666 merupakan angka binatang buas maka ada orang-orang yang menggunakannya untuk dengan menjalinnya supaya cocok dengan musuh-musuhnya. Barclay mencontohkan jika angka 666 pernah dikenakan pada Paus, John Knox, Marthin Luther, Napoleon, dan tokoh-tokoh lainnya. Penulis kuatir jika bilangan 666 ini ditafsirkan secara hurufiah, maka kekristenan akan menjadi agama tahyul, seperti yang dipercayai oleh sebagian orang yang tidak senang dengan angka 4 atau 13 karena dianggap angka sial, sebaliknya mereka sangat senang dengan angka 8 dan 9, karena dianggap membawa rejeki yang tahan lama. Oleh sebab itu perlu dipahami apa bilangan 666 tersebut.

Untuk memahami makna bilangan 666, maka perlu mengetahui latar belakangnya. Oleh sebab itu penulis melakukan studi terhadap latar belakang makna bilangan 666. Rumusan masalah dalam penulisan ini adalah apa makna bilangan 666 sesuai dengan latar belakangnya? Sementara tujuan penulisannya adalah untuk memaparkan makna bilangan 666 berdasarkan latar belakangnya.

\section{METODE}

Untuk menjawab pertanyaan dalam rumusan masalah di atas maka penulis melakukan tinjauan historis-teologis sehingga diperoleh gambaran latar belakang yang terkait dengan bilangan 666 dalam Wahyu 13. Dalam penelitian ini penulis menggunakan sumber-sumber yang membahas isu tersebut, seperti jurnal yang ditulis oleh Bryan Dawson, kemudian buku karya William Barclay. Penulis kemudian melakukan analisis terhadap sumber-sumber tersebut.

Karena pentingnya pembahasan ini, penulis menggunakan sumber-sumber yang dapat dipercaya. Untuk memastikan bahwa sumber tersebut dapat dipercaya maka, bahan literatur yang digunakan dalam penelitian ini adalah bahan literatur yang otentik dan terpublikasi (Objantoro, 2017, p. 130).

\section{HASIL DAN PEMBAHASAN}

\section{Gambaran Kitab Wahyu}

Kitab Wahyu disebut juga sebagai Kitab Apokalipsis atau dalam bahasa Yunani disebut sebagai Apokalupsis (Barclay, 2001, p. 3). Barclay (2001, p. 6-7) lebih lanjut menjelaskan bahwa Kitab Wahyu memiliki pola dan perincian yang sama dengan kitab-kitab Apokalipsis Yahudi.

Kitab Wahyu dapat di-masukkan dalam kanon alasannya menurut Guthrie (2010, p. 286) adalah karena Kitab Wahyu mengandung prinsip-prinsip yang selalu bisa diaplikasikan. Prinsip-prinsip tersebut adalah (1) Iman menang atas kekuasaan; (2) Penghakiman pasti akan datang; (3) Pendekatan Kristen menyajikan filsafat sejarah sejati, dimana Yohanes melihat zamannya dalam terang masa depan dan masa lalu. Kitab Wahyu ditulis oleh Yohanes (Lihat Wahyu 1:1-4). Dalam hal ini memang beberapa ahli tidak sependapat, tetapi sebagian besar beranggapan tidak keberatan menerima Yohanes anak Zebendeus, seorang rasul sebagai penulis kitab ini (Duyverman, 2012, p. 220). Barclay (2001, p. 17) menjelaskan bahwa Yohanes menyebut dirinya sebagai saudara bagi penerima kitab ini, kemudian Yoha- 
nes juga menyebut dirinya juga mengalami kesusahan yang sama dengan yang dialami penerima kitab ini (Lihat Wahyu 1:9).

Wahyu 13 dalam studi ini termasuk dalam garis besar bagian ketujuh sangkakala (Why. 8:2-13: 18), khususnya tentang binatang buas (Why.13:1-18) dimana ada binatang buas yang muncul dari dalam bumi. Binatang tersebut memiliki kuasa untuk menipu dengan mujizat dan mendorong manusia untuk menerima bilangannya, 666 (Guthrie, 2010, p. 289).

\section{Tinjauan Terhadap Bilangan 666}

\section{Konsep dengan Cara Gematria}

Pada zaman rasul Yohanes hidup, bahasa Yunani dan Ibrani belum mengenal angka-angka. Mereka menggunakan huruf sebagai angka (O'Brien $\&$ O’Brien, 1982, p. 107). Misalnya huruf $\beta$ (beta) un-tuk angka $2, \imath$ (iota) untuk $10, \kappa$ (kappa) untuk 20, $\rho$ (rho) untuk 100, dan seterusnya. Di dalam hal namapun, orang Yunani menghitung berapa nilai setiap huruf dari nama orang tersebut sebagai bilangan, lalu mereka menjumlah semua bilangan itu dan berkata: "itulah bilangan nama orang tersebut". Salah satu bagian dari tembok Pompeii tertulis kalimat untuk kekasihnya, "Aku mencintai seorang wanita yang nomornya 545" (Barclay, 1964, p. 131). Masyarakat Yahudi juga melakukan hal yang sama yang disebut gematria.

Pada masa kini, gematria telah digunakan oleh Al-Faqih (2017, p. 52) menggunakan gematria sebagai arahan penelitian baru dalam studi Quran.Sementara pada masa rasul Yohanes hidup, gematria sudah dikenal secara luas. Dawson (2009, p. 40) menjelaskan bahwa penggunaan gematria Yunani untuk perhitungan 666 telah lama terkenal. Penggu-naan gematria Yunani untuk penghitungan 666 juga sudah diketahui.

Seorang Bapa Gereja yang bernama Irenaeus(130-202 M) sudah memberitahukan berbagai usaha yang dilakukan untuk menafsirkan bilangan 666 de-ngan menggunakan cara gematria ini. Dia berkata, bahwa bilangan 666 menunjuk pada usaha Latinisa-si. Kata 'Latin' di dalam bahasa Yunani adalah $\lambda \alpha \tau \varepsilon$ vvoo(Lateinos) dan dijabarkan sebagai berikut: $\lambda=30, \alpha=1, \tau=300, \quad \varepsilon=5, \quad l=10$, $v=50, o=70, \sigma=200$. Jadi, jumlah seluruhnya adalah 666 (Bar-clay, 1964, p. 131).

Para penafsir setelah zaman Reformasi, yang menentang Gereja Roma Katolik, segera menerima penjelasan Irenaeus tersebut. Alasan mereka adalah bahasa yang dipakai di dalam kekaisaran Romawi adalah Latin, uskup Roma memakai Alkitab bahasa Latin (Vulgata), puji-pujian dan liturgi ibadah mereka juga memakai bahasa Latin. Maka, menurut tafsiran mereka, bilangan 666 adalah sebagai lambang keuskupan dan pengajaran agama Roma Katolik. Tafsiran lain, mengaitkan bilangan 666 dengan nama kaisar 'Nero', yang dalam bahasa Latin disebut 'Neron'. Penjabarannya adalah:

$$
\begin{gathered}
v=50 \\
\varepsilon=6 \\
\rho=500 \\
o=60 \\
v=50
\end{gathered}
$$

Jadi jumlah seluruhnya sama dengan 666. Penafsiran ini mempunyai kelemahan, yakni jika huruf akhir ' $v$ ' dihapuskan, maka jumlahnya hanya 616. Selain itu, mengapa huruf $\varepsilon$ bernilai 6 , seharusnya 5 (Bnd. Nekrasov, 2013, p. 159-160). Tenney (2009, p. 476) berpendapat penalaran bahwa 'nomor keramat dalam Wahyu 13:18 adalah jumlah keseluruhan dari huruf yang mengeja nama Neron Kesar, sehingga yang dimaksud dalam pasal tersebut pastilah Nero' terlalu lemah untuk menjamin kesimpulan pasti, terutama jika tidak ada dukungan tradisi eksternal. Tafsiran berikutnya mengacu pada kata Teitan dalam huruf Yunani: $T=300, \varepsilon=5, \imath=10, \tau=300, \alpha=1, v=$ 50, jadi jumlahnya adalah 666. Kata Teitan memiliki 2 arti, yakni: pertama, dalam mitologi Yunani, para Titan adalah pemberontak melawan Allah. Makna kedua, nama marga dari 3 kaisar Romawi, yakni: Vespasian (69-79 M), Titus (79-81 M), dan Domitianus (81-96 M) adalah Titus, dan kemungkinan mereka dapat disebut Titans (Barclay, 1964, p. 131). 
Dawson (2009, p. 40) mengatakan bahwa Luther pernah menyimpulkan bahwa 666 mungkin merujuk pada seorang paus bernama Benediktus atau seorang biarawan Benediktin. Demikian perhitungannya

$\begin{array}{ccccccccccc}\beta & \varepsilon & \nu & \varepsilon & \delta & \imath & \kappa & \tau & v & \sigma & \\ 2 & 5 & 50 & 5 & 4 & 10 & 20 & 300 & 70 & 200 & =666\end{array}$

Walaupun sudah puluhan nama yang telah diusulkan dan bernilai bilangan 666, tetapi masih belum jelas nama mana yang tepat. Sudah tentu haruslah ditolak jika metode gematria tersebut dikenakan kepada nama pribadi-pribadi yang hidup pada zaman modern apalagi pada masa sekarang ini, sebab masyarakatnya telah mengenal angka biasa.

Misalnya, pada masa Perang Dunia II, sebagian penafsir mengait-ngaitkan bilangan ini dengan nama 'Hitler'. Cuma huruf A sebagai huruf pertama bernilai 100 bukan seperti biasanya bernilai 1. Penjabarannya adalah sebagai berikut: $\mathrm{H}=107, \mathrm{i}=108$, $\mathrm{t}=119, \mathrm{l}=111, \mathrm{e}=104, \mathrm{r}=117$. Jadi, jumlahnya adalah 666 (Barclay, 1964, p. 131).

Morris Cerullo (1994, p. 15-27) menafsirkan bilangan 666 sebagai sistim ekonomi global yang akan terlaksana pada tahun 1999 melalui pemasangan microchip dalam tubuh manusia maupun binatang. Namun, setelah melewati tahun 1999, terbuktilah, bahwa tafsirannya tidaklah benar.

Dawson (2009, p. 40) menjelaskan bahwa memang gematria telah digunakan dalam pengkodean huruf standar untuk angka dalam bahasa Yunani, tetapi dalam melakukan studi terkait bilangan 666 perlu kehati-hatian. Lebih lanjut Dawson menjelaskan bahwa karena banyak nama juga bisa dikuasai dengan menggunakan bahasa Yunani gematria, maka harus berhati-hati dalam menarik kesimpulan berdasarkan penghitungan itu sendiri tanpa bukti pendukung dan harus sesuai dengan karakteristik lain yang disebutkan dalam kitab suci. Bagi penulis, penafsiran terhadap bilangan 666 dengan menggunakan gematria tidak dapat diterima dan masih perlu diuji dengan lebih dalam sehingga tidak menimbulkan dugaan-dugaan yang tidak tepat.

\section{Konteks Wahyu 13}

Rahasia bilangan 666 itu pastilah dapat dipahami oleh para pembaca pertama dari kitab Wahyu ini, yakni mereka yang hidup pada zaman rasul Yohanes hidup; jika tidak demikian pastilah kitab ini tidak ada faedahnya bagi mereka. Namun, bagi kita yang hidup pada zaman sekarang ini sulit memahami maknanya dengan pasti.

Dalam hal ini perlu melihat konteks ayat tersebut, yakni di Wahyu 13 yang menuliskan pemunculan dua ekor binatang buas, yakni: pertama, binatang yang keluar dari dalam laut. Laut adalah melambangkan bangsa-bangsa (bnd. Why. 17:15). Jadi, binatang pertama ini adalah simbol dari kuasa pemerintahan yang melawan Tuhan, yakni kekaisaran Romawi. Binatang itu mempunyai 7 kepala dan 10 tanduk. Ini menunjuk pada 7 kaisar yang berkuasa dari th. 14-96 M, yakni: Tiberius, Caligula, Claudius, Nero, Vespasian, Titus, dan Domitianus. Namun, ada 3 orang lagi yang memimpin secara singkat setelah kematian Nero, yakni: Servius Sulpicius Galba (6 bulan), Markus Salvius Otho (95 hari), dan Kwintus Vitellius (kurang dari 1 tahun); sehingga ketiga pemimpin ini tidak sepenting dari ketujuh kaisar tersebut (Why. 13:1). Jadi, kombinasi antara 7 kaisar dan 3 pemimpin sementara itu menjadikan 10 tanduk (Ludwig, 1976, p. 85-87; O’Brien \& O’Brien, 1982, p. 104).

Kaisar Domitianus mengharuskan semua rakyat Romawi untuk menyembahnya sebagai dewa. Setiap tahun sekali, setiap warga harus mempersembahkan kemenyan dan berkata, "Kaisar adalah Tuhan". Setelah orang itu melakukannya, ia bebas untuk beribadah menurut agamanya sendiri. Penyembahan kepada kaisar dijadikan sebagai alat pemersatu bagi seluruh daerah kekuasaan Romawi yang luas itu. Namun sebenarnya, penyembahan tersebut didalangi oleh kuasa Setan, sehingga orang Kristen menolaknya. Mereka berkata, hanya 'Kristuslah Tuhan', sehingga umat Tuhan dianggap sebagai pembangkang politis.

Kemudian dikatakan, "Maka tampaklah kepadaku satu dari kepala-kepalanya seperti kena luka 
yang membahayakan hidupnya, tetapi luka yang membahayakan hidupnya itu sembuh. Seluruh dunia heran, lalu mengikut binatang itu" (Why. 13:3). Menurut konteksnya, ayat ini menunjuk pada kaisar Nero yang memerintah dari th. 55-68 M. Sifatnya terkenal buruk, kejam seperti monster. Nero, yang memenggal kepala rasul Paulus, adalah kaisar pertama Romawi yang menjadikan aniaya terhadap umat Kristen sebagai kebijakan pemerintahannya. Pada saat kematiannya (68 M) yang membunuh diri itu, rakyat menari-nari di jalan. Setelah tentara Romawi memberontak terhadap Nero di Spanyol, Galba dinyatakan sebagai kaisar baru. Senat menetapkan Nero sebagai seorang buangan yang membuatnya melarikan diri dari kota Roma secara menyamar. Pada suatu malam pada bulan Juni, dalam keadaan terpojok, ia merangkak ke dalam suatu ruang bawah tanah. Di tempat itu, di atas tempat tidur kecil, dalam keadaan gemetar ketakutan, ia mencoba untuk bunuh diri. Namun, pisaunya tidak cukup dalam, sehingga ia meminta kepada pelayannya, Epafroditus, untuk mendorong mata pisau itu lebih dalam lagi dan membuatnya mati (Ludwig, 1976, p. 81). Namun, setelah itu muncul dan berkembanglah suatu isu dalam masyarakat, bahwa Nero tidak benar-benar mati. Ia dipercayai pergi ke Parthia (musuh Romawi di bagian Timur yang paling berbahaya); dan pada suatu hari ia akan kembali dengan memimpin tentara Parthia melawan kekaisaran Romawi. Pada akhir tahun 80 M, seseorang dari Parthia mengklaim diri sebagai Nero. Ia hampir saja berhasil membujuk rakyat Parthia untuk menyerang Eropa di bawah pimpinannya (Barclay, 1964, p. 116). Legenda ini dikenal sebagai 'Nero bangkit kembali' (Nero redivivus).

Orang-orang Kristen pada abad pertama mengidentikkan Antikris seperti 'Nero yang bangkit kembali' itu (Barclay, 1964, p. 116). Hal tersebut dikarenakan latar belakang dan kehidupan Nero yang begitu jahat. Kakeknya (dari pihak ayah) adalah pemboros dan gemar melihat pertandingan gladiator. Ia bersikap sangat kejam terhadap para budaknya. Ayah Nero (Gnaeus Domitius) adalah seorang yang mesum karena suka berjinah dengan saudara kandungnya sendiri. Ia menikah dengan Agripina (ibu Nero) yang ketika itu masih berusia 13 tahun.

Tidak lama setelah menjadi kaisar pada usia 17 tahun, Nero meracuni Britanikus, saudara tirinya yang menjadi saingannya yang kuat. Kemudian, ibunya sendiri, Agripina, menjadi korban berikutnya karena dianggap bersekongkol untuk membunuh sang kaisar. Setelah itu, ia membunuh bibi yang telah berjasa membesarkannya; membuang Oktavia (saudara Britanikus) yang telah dinikahinya pada waktu berusia 16 tahun. Lalu, sang kaisar memerintahkan Oktavia untuk membunuh dirinya sendiri. Nero menendang Poppaea, istri barunya yang sedang hamil, sehingga meninggal dunia. Lalu, ia menikahi Sporus, seorang pemuda yang dikebiri karena perintahnya. Puncak kejahatannya terjadi ketika ia mengkambing-hitamkan orang-orang Kristen atas kebakaran yang menghanguskan $2 / 3$ bagian dari kota Roma. Akibatnya, rakyat Roma menganiaya dan membunuh umat Tuhan secara kejam. Paulus mati dipenggal kepalanya pada saat Nero berkuasa (Ludwig, 1976, p. 73-80).

'Binatang yang keluar dari laut' itu diijinkan Tuhan untuk menganiaya bahkan membunuh banyak umat-Nya. Skope kekuasaannya adalah universal yang meliputi setiap suku bangsa. Namun Allah, yang memelihara umat-Nya, telah membatasi penganiayaan tersebut selama 42 bulan saja $(=31 / 2$ tahun, yang berarti setengah dari angka 7). Angka 7 melambangkan tidak terbatas. Misalnya: Yesus mengajar Petrus untuk mengampuni saudaranya yang bersalah kepadanya sebanyak 70 x 7 kali (Mat. 18:22), maksudnya adalah jumlah yang tidak terbatas. Jadi, Petrus harus selalu bersedia mengampuni saudaranya itu. Sedangkan $31 / 2$ adalah 7 dibagi 2 , lambang keterbatasan. Jadi, angka $31 / 2$ janganlah ditafsirkan secara hurufiah, tetapi melambangkan jumlah waktu yang terbatas (Why. 13:5).

Binatang kedua keluar dari dalam bumi yang menyatakan, bahwa pemunculannya berasal dari tatanan dunia yang mapan. Nampaknya seperti domba. Domba berkonotasi agamawi, misalnya: orang Ya- 
hudi menjadikan domba sebagai salah satu korban bakaran mereka kepada Allah. Domba itu mempunyai 2 tanduk yang menyimbolkan kekuasaan (Why. 13:11). Jika binatang yang keluar dari dalam laut melambangkan kekaisaran Romawi, maka binatang yang keluar dari bumi adalah simbol dari nabi palsu yang memotivasi rakyat dan mengatur penyembahan kepada sang kaisar. Kedua binatang tersebut diberi kuasa oleh Setan. Adalah hal yang sangat berbahaya jika kuasa politis yang jahat berkombinasi dengan agama palsu yang menopangnya. Untuk menyesatkan banyak orang, maka sang nabi palsu tersebut diberi kuasa Satanis untuk melakukan mujizatmujizat yang dahsyat, salah satunya adalah mendatangkan api dari langit, seperti yang dilakukan oleh nabi Elia (1 Raj. 18:38).

Setiap orang, besar atau kecil, kaya atau miskin, orang merdeka atau hamba diharuskan untuk mendapatkan tanda di tangan kanan atau dahi mereka. Tanpa tanda itu, tidak ada seorangpun boleh membeli atau menjual barang. Pemberian meterai kepada para budak, tentara, dan dalam kontrak bisnis adalah hal yang biasa pada zaman itu. Setelah warga Romawi membakar kemenyan di hadapan patung sang kaisar setiap tahunnya, maka mereka diberikan sertifikat tanda ketaatan. Dengan sertifikat itu, mereka bebas dari hukuman kaisar dan dapat berjual-beli secara bebas pula.

Bilangan binatang itu adalah 666 (Why. 13: 18). Di dalam kitab Wahyu yang berisikan banyak simbol, angka 7 adalah lambang dari ketidakterbatasan dan keseluruhan. Tuhan Yesus mengalamatkan surat-Nya kepada 7 jemaat (Why. 2-3), yang melambangkan keseluruhan jemaat Tuhan yang ada di dunia ini sepanjang sejarah gereja. Angka 6 muncul seolah-olah mau naik menjadi angka 7 , namun tidak dapat mencapainya. Jadi, angka 6 menunjuk pada usaha manusia yang terbatas. Angka 6 itu diulangi 3 kali. Angka 3 adalah simbol angka Ilahi (bnd. Allah Tritunggal). Dengan demikian, bilangan 666 melambangkan usaha manusia yang berusaha menyamai Allah untuk mencapai kuasa yang tidak terbatas, namun mereka gagal.
Sebenarnya, roh antikristus sudah mulai bekerja sejak zaman rasul Yohanes hidup. Sang rasul menyerang pengajaran nabi-nabi palsu yang dipengaruhi oleh Gnosticisme. Mereka berusaha menyesatkan umat Tuhan dengan menyangkali doktrin inkarnasi (Barclay, 1962, p. 7). Menurut mereka, tubuh manusia (sarx, daging) adalah jahat, sedangkan roh itu suci. Jadi, tidaklah mungkin sang Logos (yang adalah Allah) menjadi daging. Yesus, menurut Gnosticisme, adalah Allah namun bukanlah manusia yang sesungguhnya. Terhadap ajaran tersebut, sang rasul perlu membimbing umat-Nya dengan pengajaran yang jelas, yakni: "Logos (Firman) itu menjadi manusia (daging, sarx)" (Yoh. 1:14). Selain itu, sang Rasul mengingatkan jemaat-Nya,

Demikianlah kita mengenal Roh Allah: setiap roh yang mengaku, bahwa Yesus Kristus telah datang sebagai manusia ( $\operatorname{sarx}=$ daging) berasal dari Allah, dan setiap roh, yang tidak mengaku Yesus, tidak berasal dari Allah. Roh itu adalah roh antikristus dan tentang dia telah kamu dengar, bahwa ia akan datang dan sekarang ini ia sudah ada di dalam dunia (1 Yoh. 4:2-3).

Sepanjang sejarah dunia ini, manusia yang berdosa dalam kecongkakan mereka, selalu berusaha untuk menyamai Allah. Hal ini terlihat dari berbagai tindakan dan pemikiran mereka di dalam sejarah dunia ini. Peristiwa Menara Babel (Kej. 11:1-9), raja Babel yang angkuh (Yes. 14:13-14), raja Nebukadnezar (Dan. 4:29), beberapa kaisar Romawi yang mengklaim diri sebagai dewa, dan sebagian pemimpin negara lainnya yang pernah memutlakkan diri pada saat mereja berjaya. Namun, Allah sang Raja segala raja menurunkan orang-orang yang congkak dari tahta mereka, seperti yang dikatakan oleh Maria, "Ia menurunkan orang-orang yang berkuasa dari tahtanya dan meninggikan orang-orang yang rendah" (Luk. 1:52).

Filsafat Rasionalisme muncul di Eropa pada abad ke-17. Menurut filsafat ini, sumber pengetahuan yang mencukupi dan yang dapat dipercaya adalah rasio (akal). Akal dapat menurunkan kebenaran dari dirinya sendiri (Hadiwijono, 2006, p. 18). Kaum rasionalis cenderung memutlakkan akal, sehingga segala sesuatu yang tidak masuk akal ditolak. Oleh ka- 
rena itu, hal-hal yang bersifat supranatural dan mujizat ditolak. Kejadian Yesus dilahirkan oleh anak dara Maria ditolak; demikian pula dengan semua mujizat dan fakta kebangkitan Yesus ditolak mereka. Rasionalisme menempatkan akal manusia di atas segala-galanya. Bukankah filsafat tersebut juga dipengaruhi oleh roh antikris? Padahal, sebenarnya ada 3 area yang berkaitan dengan akal, yakni hal-hal yang: masuk akal, tidak masuk akal, dan melampaui akal. Masalah mujizat, supranatural, dan hal-hal yang bersifat Ilahi berada di area melampaui akal manusia yang terbatas.

Pada akhir abad 20 yang lalu muncullah New Age Movement (Gerakan Zaman Baru). Salah satu klaim yang menggiurkan dari gerakan ini adalah: "Kita bukan saja sempurna; faktanya, kita adalah allah-allah." Manusia adalah allah secara tersamar (Groothuis, 2000, p. 23). Theodore Roszak (1977, p. 225) berkata, "Tujuan kita adalah membangunkan allah yang sedang tertidur di dalam hakikat manusia yang terdalam.” L.L. Whyte (1974, p. 6), filsuf dan pelopor gerakan ini berkata secara terbuka,

Sudah sejak sangat lama setiap orang yang menyangkali Allah (yang transenden) akan meninggikan keilahian dirinya sendiri. Dengan menjatuhkan Allah, manusia memulihkan dirinya sendiri. Kini waktunya Allah harus diletakkan pada tempatnya, yaitu di dalam manusia, dan tidak ada yang mustahil untuk melakukan hal itu.

Dengan melihat pengajaran New Age Movement secara sekilas, dapat disimpulkan, bahwa ajaran tersebut jelas ditunggangi oleh roh antikris yang menanamkan di dalam hati para pengikutnya suatu sifat angkuh yang mengklaim diri sebagai Allah.

Kitab Wahyu menyatakan bahwa Iblis menyerang umat Tuhan dengan sangat gencar, baik dari sudut agama palsu maupun dari sistim politik yang melawan kehendak Tuhan. Namun, semua itu hanya

\section{DAFTAR RUJUKAN}

Al-Faqih, Khaled Mahmoud Salim. 2017. "A Mathematical Phenomenon in the Quran of EarthShattering Proportions: A Quranic Theory terbatas kuasanya dan tidak mungkin melenyapkan gereja Tuhan dari muka bumi ini. Di tengah-tengah penganiayaan apapun juga, umat Tuhan harus mengingat kemenangan Kristus, sehingga iman mereka dikuatkan, seperti perkataan Yesus sebagai berikut "Engkau adalah Petrus dan di atas batu karang ini (cat.: yakni pengakuan bahwa Tuhan Yesus adalah Mesias, Anak Allah) Aku akan mendirikan jemaat$\mathrm{Ku}$ (cat.=gereja-Ku) dan alam maut (cat.: musuh terbesar manusia) tidak dapat menguasainya" (Mat. 16:18).

\section{KESIMPULAN}

Bilangan '666' di dalam kitab Wahyu janganlah ditafsirkan secara hurufiah, misalnya dengan menggunakan konsep gematria, tetapi secara makna simbolis, sesuai dengan karakter literatur apocalyptic. Penggunaan metode gematriadalam mengkaji bilangan 666 harus ditolak jika dikenakan kepada nama pribadi-pribadi yang hidup pada zaman modern apalagi pada masa sekarang ini, sebab masyarakatnya telah mengenal angka biasa.

Kemudian hasil analisis terhadap konteks Wahyu 13 maka kitab Wahyu berisikan banyak simbol, kemudian bilangan 666 melambangkan usaha manusia yang berusaha menyamai Allah untuk mencapai kuasa yang tidak terbatas, namun mereka gagal. Selanjutnya jika binatang yang keluar dari dalam laut melambangkan kekaisaran Romawi, maka binatang yang keluar dari bumi adalah simbol dari nabi palsu yang memotivasi rakyat dan mengatur penyembahan kepada sang kaisar. Terkadang roh antikris itu menjelma dalam bentuk filsafat yang berlawanan dengan firman Tuhan; atau dalam pribadi-pribadi tertentu yang menjadi tokoh di dunia politik atau agama tertentu yang berusaha menentang kehendak Allah maupun kebenaran Alkitab.

Based on Gematria Determining Quran Primary Statistics (words, verses, chapters) and Revealing its Fascinating Connection with 
the Golden Ratio," Journal of Arts \& Humanities, 06 (06): 52-73.

Barclay, William. 1962. The Letters of John and Jude. Edinburgh: The Saint Andrew Press.

Barclay, William. 1964. The Revelation of John, vol.

2. Edinburgh: The Saint Andrew Press.

Barclay, William. 2001. Pemahaman Alkitab Setiap

Hari: Wahyu Kepada Yohanes Pasal 1-5. Jakarta: BPK Gunung Mulia.

Barclay, William. 2007. Pemahaman Alkitab Setiap Hari: Wahyu Kepada Yohanes Pasal 6-22. Jakarta: BPK Gunung Mulia.

Cerullo, M. 1994. 666 Menjelang 1999? Waspadalah Terhadap Munculnya Sistem Ekonomi Global! Surabaya: Global Satellite Network.

Dawson, Briyan. 2009. "Arithmetic Sequences, Diophantine Equations, and the Number of the Beast," Journal of the Union Faculty Forumm, 29: 33-41.

Duyverman, M.E. 2012. Pembimbing ke Dalam Perjanjian Baru. Jakarta: BPK Gunung Mulia.

Groothuis, Douglas R. 2000. Membuka Topeng Gerakan Zaman Baru. Jakarta: STEMI.

Guthrie, Donald. 2010. Pengantar Perjanjian Baru, Volume 3. Surabaya: Momentum.

Hadiwijono, Harun. 2006. Sari Sejarah Filsafat Barat 2. Jogyakarta: Penerbit Kanisius.
Ludwig, C. 1976. Para Penguasa: Pada Zaman Perjanjian Baru. Bandung: Kalam Hidup.

Nekrasov, S.A. 2013. "Numerically-linguistic Anomalies of Gematria," Sociology and Anthropology, 1 (3): 158-163.

O’Brien, Chester C. \& Bonnie Ball O’Brien. 1982. The Victory of The Lamb: A Study of the Book of Revelation. Makati, Philippines: PhilBEST Publications.

Objantoro, Enggar. 2017. "Sejarah Dan Pemikiran Kaum Injili Di Tengah-Tengah Perubahan dan Tantangan Zaman", Evangelikal: Jurnal Teologi Injili dan Pembinaan Warga Jemaat, 1 (2): 129-138.

Relfe, Mary Stewart. 1982. The New Money System. Montgomery, Alabama: Ministries, Inc., buku terjemahan dalam bahasa Indonesia Relfe, Mary Stewart. 1995. “666” \& Sistem Mata Uang Baru. Solo: Dabara Publishers Division.

Roszak, Theodore. 1977. Unfinished Animal. New York: Harper and Row.

Tenney, Merrill C. 2009. Survei Perjanjian Baru. Malang: Gandum Mas.

Whyte, Lancelot Law. 1974. The Universe of Experience. New York: Harper and Row. 